\title{
PENGEMBANGAN MEDIA BOOKLET SCIENCE FOR KIDS SEBAGAI SUMBER BELAJAR DI SEKOLAH DASAR
}

\author{
Tiurida Intika
}

\author{
Pendidikan Dasar, Pascasarjana Universitas Negeri Semarang, Semarang, Indonesia
}

Korespondensi. E-mail: Tiuridaintika@gmail.com

\begin{abstract}
Abstrak
Media booklet dapat dijadikan sumber belajar karena bentuknya sederhana serta menyediakan data akurat yang dapat membantu siswa memahami konsep materi. Tujuan pengembangan adalah untuk mengetahui pentingnya cara pengembangan serta efektivitasnya. Penelitian ini merupakan penelitian Research and Development (R\&D) yang dilakukan mengacu pada teori Borg dan Gall. Data yang diambil adalah kebutuhan pengembangan booklet, kelayakan booklet, tanggapan siswa mengenai kelayakan booklet dan hasil belajar siswa melalui media booklet. Hasil penelitian menunjukkan bahwa guru dan siswa memberikan tanggapan positif terhadap penggunaan booklet. Terlihat pada penilaian validasi produk booklet dari pakar materi dan media yang memperoleh skor rata-rata 3,28 dengan kriteria sangat baik atau layak digunakan. Siswa memberikan tanggapan dan respon positif sangat baik dengan memperoleh skor rata-rata sebesar $9,26 \%$. Sedangkan ketuntasan hasil belajar siswa dengan $\geq 75$ pada uji coba pemakaian 84,5\%. Berdasarkan hasil penelitian dapat disimpulkan bahwa media booklet science for kids booklet efektif dan layak digunakan untuk meningkatkan hasil belajar siswa dan dikembangkan berdasarakan kebutuhan guru dan siswa.
\end{abstract}

Kata Kunci : Media Booklet, Sumber Belajar, Hasil Belajar

\section{DEVELOPMENT OF BOOKLET SCIENCE MEDIA FOR KIDS AS A RESOURCE LEARNING IN BASIC SCHOOL}

\begin{abstract}
Media booklet can be used as a source of learning because it is simple and provides accurate data that can help students understand the concept of the material. The purpose of development is to know the importance of development and its effectiveness. This research is a Research and Development $(R \& D)$ research which is done referring to Borg and Gall theory. The data taken is the need of booklet development, booklet feasibility, student responses about booklet feasibility and student learning outcomes through booklet media. The results showed that teachers and students responded positively to the use of booklets. Seen on the validation assessment of product booklets from material and media experts who scored an average of 3.28 with criteria very good or feasible to use. Students responded positively very well with an average score of $9.26 \%$. While the completeness of student learning outcomes with $\geq 75$ on the trial use $84.5 \%$. Based on the results of the study can be concluded that the media booklet science for kids booklet effective and worthy used to improve student learning outcomes and developed based on the needs of teachers and students.
\end{abstract}

Keywords: Media Booklet, Learning Resources, Learning Outcomes

Copyright @2018, JRPD, ISSN 2615 - 1723 (Print), ISSN 2615 - 1766 (Online) 


\section{PENDAHULUAN}

Dalam suatu proses belajar mengajar peran guru di sekolah sangatlah dibutuhkan dalam membantu siswanya untuk mencapai hasil belajar yang optimal. Tetapi, kita ketahui bahwa di dalam proses belajar bukan hanya guru tetapi juga falisitas yang digunakan juga dapat menunjang proses belajar mengajar agar lebih baik dan efektif.

Media pembelajaran adalah perantara yang berupa sumber belajar atau bentuk fisik yang mengandung materi instruksional yang dapat dimanfaatkan guru dan siswa untuk menunjang kegiatan belajar. Arsyad (2010) menjelaskan bahwa media pembelajaran dapat memperjelas penyajian pesan atau informasi sehingga dapat memperlancar dan meningkatkan proses dan hasil belajar.

Berdasarkan hasil observasi di kelas VB SD Negeri Tugurejo 01 di peroleh informasi bahwa di saat pembelajaran berlangsung proses pembelajaran kurang efektif karena masih sedikit atau minimnya sumber belajar yang digunakan, hanya tersedia buku teks dan LKS.

Apabila siswa membuka sebuah buku teks pelajaran, yang ditemukan adalah halaman yang penuh dengan deretan tulisan kecil-kecil, terkadang dilengkapi dengan gambar ataupun diagram. Semua itu disusun dengan layout yang kaku demi memaksimalkan tempat yang ada. Sehingga siswa lebih memahami suatu konsep jika pembelajaran disajikan tidak hanya dengan kata-kata tetapi dilengkapi dengan gambar (Mayer, 2009).

Oleh karena itu, dibutuhkan sumber belajar yang praktis dan sesuai dengan kebutuhan siswa. Hasil observasi pada beberapa siswa kelas VB di SD Negeri Tugurejo 01 menyatakan bahwa mereka lebih menyukai pembelajaran yang menggunakan media gambar dan foto serta siswa lebih menyukai buku teks atau bahan ajar yang tidak terlalu tebal. Sehingga akan di rancang atau di buat pengembangan media pembelajaran berbentuk booklet sebagai media pembelajaran yang efektif dan efisien.

Hal tersebut didukung oleh Nur (2012) yang menyatakan bahwa untuk memilih buku yang perlu mencakup dan mempertimbangkan isi buku, ketepatan konsep, keaktualan informasi, kesesuaian contoh, dan keluasan serta kedalaman materi.

Media pembelajaran booklet merupakan kelompok media teknologi cetak. Booklet adalah sebuah buku kecil yang memiliki paling sedikit lima halaman tetapi tidak lebih dari empat puluh delapan halaman diluar hitungan sampul (Darmoko, 2012). Booklet berisikan informasi-informasi penting, isinya harus jelas, tegas, mudah dimengerti dan akan lebih menarik jika booklet tersebut disertai dengan gambar, sehingga booklet ini menjadi media pendamping untuk kegiatan pembelajaran di kelas dan diharapkan bisa meningkatkan efektivitas pembelajaran peserta didik.

Bentuknya yang kecil menjadikan booklet mudah dibawa kemana-mana. Selain itu booklet yang berisikan tentang informasi-informasi penting disertai gambar ilustrasi memudahkan peserta didik menggunakan dalam proses pembelajaran menurut Pralisaputri, et al. (2016).

Penelitian ini bertujuan untuk : 1) Mengembangkan booklet sebagai sumber belajar, 2) Menganalisis kevalidan media pembelajaran berbentuk booklet yang dikembangkan, 3) Menganalisis keefektifan dan kepraktisan media pembelajaran berbentuk booklet SD Negeri Tugurejo 01 Semarang. 


\section{Jurnal Riset Pendidikan Dasar, 01 (1), April 2018 (10-17)}

Tiurida Intika

\section{METODE}

Lokasi penelitian adalah di SD Negeri Tugurejo 01 Semarang pada siswa kelas V semester ganjil tahun ajaran 2016/2017. Jenis atau metode yang digunakan dalam penelitian ini adalah Research and Development (R\&D). Produk yang dikembangkan adalah media booklet science for kids dengan materi pembelajaran IPA sifat dan perubahan benda sebagai sumber belajar siswa di kelas V.

Penelitian ini merupakan penelitian Research and Development (R\&D) yang mengacu pada teori Borg dan Gall (Sugiyono, 2015) yaitu studi pendahuluan, perencanaan, penyusunan, dan validasi, uji produk, evaluasi, revisi,serta penyempurnaan untuk memperoleh produk jadi. Langkah-langkah tersebut akan dilakukan yaitu (1) melakukan pengumpulan informasi mengenai materi yang ada di sekolah yang menjadi aspek penelitian; (2) melakukan perancangan termasuk merumuskan tujuan penelitian, memperkirakan dana dan waktu yang diperlukan; (3) mengembangkan bentuk awal materi IPA untuk menumbuhkan keaktifan; (4) melakukan uji coba lapangan permulaan; (5) melakukan revisi terhadap materi IPA untuk menumbuhkan keaktifan belajar siswa; (6) melakukan uji lapangan operasional. Sesuai kebutuhan penelitian dan kondisi penelitian yang sebenarnya, terhadap penelitian dihentikan pada tahap keenam.

Selanjutnya, media booklet science for kids diuji efektivitas dan kepraktisan bagi guru dan siswa saat digunakan dalam pembelajaran. Validasi yang dilakukan yaitu pada desain booklet oleh validator materi dan media yang merupakan dosen FMIPA UNNES dan dosen Universitas PGRI Palembang. Aspek yang dinilai yaitu aspek materi, aspek desain pembelajaran dan media, dan aspek bahasa. Saran dari validator digunakan untuk merevisi desain yang selanjutnya dilakukan uji coba awal untuk mengetahui keterbacaan booklet berdasarkan tanggapan siswa.

Penelitian ini diawali dengan melakukan observasi kelas. Observasi dilakukan di kelas VB Sekolah Dasar Negeri Tugurejo 01 Kota Semarang. Tujuan dari observasi adalah untuk mengetahui kelayakan dari media pembelajaran booklet yang dibuat sebagai sumber belajar siswa.

Materi yang dikaji pada penelitian ini adalah materi sifat dan perubahan benda. Data yang diambil terdiri dari tanggapan guru mengenai kebutuhan pengembangan booklet dan tanggapan siswa terhadap kelayakan booklet sebagai sumber belajar serta data hasil belajar siswa.

Sedangkan untuk menilai keefektifan pada siswa dinyatakan efektif jika sebanyak $75 \%$ soal pada lembar soal siswa dapat terjawab melalui media pembelajaran booklet science for kids sebagai sumber belajar. Hal tersebut sesuai dengan yang dikemukakan Parveen (2011) untuk mengajar secara efektif, guru harus memiliki pengetahuan yang cukup tentang siswa, selain pengetahuan tentang metode subjek dan tepat pengajaran.

Data hasil kerja siswa akan dianalisis dengan cara menghitung persentase jawaban benar dengan rumus sebagai berikut:

$$
\mathrm{E}=\frac{\text { Jawaban benar }}{\text { Jumlah soal }} \times 100 \%
$$

Keterangan :

$\mathrm{E}=$ Efektivitas

Keriteria keberhasilah berdasarkan uji efektivitas dapat ditentukan dengan indikator sebagai berikut.

\section{Tabel 1 Kriteria Efektivitas}

\begin{tabular}{cc}
\hline$<\mathrm{E}>$ & Kriteria \\
\hline $75 \geq \mathrm{E}$ & Efektif \\
$50 \geq \mathrm{E}<75$ & Kurang Efektif \\
\hline
\end{tabular}

Kurang Efektif 


\begin{tabular}{cl}
\hline $0 \geq \mathrm{E}$ & Tidak Efektif \\
\hline Pengembangan & booklet pada
\end{tabular}
penelitian ini dikatakan berhasil apabila hasil analisis pengukuran kelayakannya mencapai $>70 \%$, di katakan praktis apabila mencapai $\geq 85 \%$, dan dikatakan efektif apabila tuntas belajar dengan memperoleh nilai tes hasil belajar $\geq 80 \%$ dari jumlah siswa yang ada di kelas.

\section{HASIL}

Hasil penelitian pengembangan booklet science for kids sebagai sumber belajar pada materi sifat dan perubahan benda meliputi analisis kebutuhan pengembangan booklet, penilaian kelayakan desain, uji coba awal dan uji coba pemakaian. Hasil pengisian angket kebutuhan menunjukkan bahwa guru kelas VB memberikan tanggapan yang positif mengenai adanya booklet science for kids.

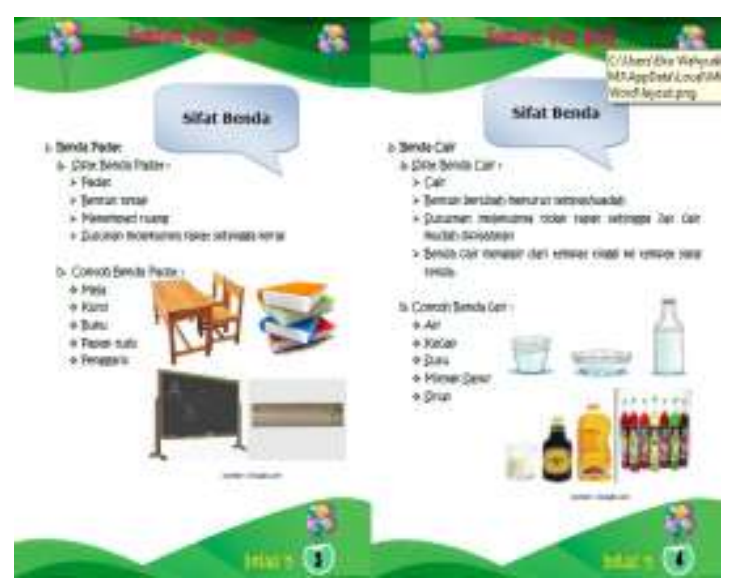

Gambar 1. Contoh isi materi booklet

\section{Kelayakan}

Hasil analisis terhadap penilaian kelayakan dilakukan oleh pakar materi dan media yang bertujuan untuk merevisi booklet yang di kembangkan. Hasil penilaian kelayakan dari validator materi dan media dapat dilihat pada Tabel 2

Tabel 2 Hasil validasi produk oleh validator

\begin{tabular}{|c|c|c|c|c|c|c|c|}
\hline \multirow{3}{*}{ No } & \multirow{3}{*}{ Kode } & & Skc & & \multirow{3}{*}{$\begin{array}{l}\text { Skor } \\
\text { Total }\end{array}$} & \multirow{3}{*}{$\begin{array}{c}\text { Rata-rata } \\
\text { Skor }\end{array}$} & \multirow{3}{*}{ Kategori } \\
\hline & & \multicolumn{3}{|c|}{ Aspek Komponen } & & & \\
\hline & & Isi & Bahasa & Penyajian & & & \\
\hline 1 & V-1 & 26 & 40 & 50 & 116 & 3.05 & Baik \\
\hline 2 & $\mathrm{~V}-2$ & 34 & 45 & 55 & 134 & 3.52 & Sangat Baik \\
\hline \multicolumn{5}{|c|}{ Rata-rata keseluruhan (total item 38) } & & 3.28 & Sangat Baik \\
\hline
\end{tabular}

Berdasarkan hasil penilaian validator diatas maka diperoleh simpulan bahwa media pembelajaran yang dikembangkan valid dan sangat baik.

\section{Kepraktisan}

Berdasarkan hasil yang dilakukan menunjukkan bahwa respon yang didapat secara keseluruhan siswa pada uji coba memberikan tanggapan positif terhadap booklet science for kids materi sifat dan perubahan benda sebagai sumber belajar siswa. Rekapitulasi angket siswa terhadap keterbacaan buklet tercantum pada Tabel 3.

Tabel 3 Rekapitulasi angket respon siswa

\begin{tabular}{clcc}
\hline \multirow{2}{*}{ No } & \multicolumn{1}{c}{ Pernyataan } & \multicolumn{2}{c}{ Respon (\%) } \\
\cline { 2 - 4 } & Ya & Tidak \\
\hline 1 & $\begin{array}{l}\text { Membuat saya ingin } \\
\text { selalu belajar }\end{array}$ & 100 & 0 \\
2 & $\begin{array}{l}\text { Membuat saya senang } \\
\text { belajar }\end{array}$ & 95 & 5 \\
3 & Menarik perhatian & 93 & 7 \\
4 & $\begin{array}{l}\text { Rasa ingin tahu dapat } \\
\text { dimunculkan }\end{array}$ & 75 & 25 \\
5 & Aktif dalam belajar & 97 & 3 \\
6 & Tidak menemukan & 85 & 15
\end{tabular}

Copyright $@ 2018$, JRPD, ISSN 2615 - 1723 (Print), ISSN 2615 - 1766 (Online) 


\begin{tabular}{|c|c|c|c|}
\hline \multicolumn{4}{|c|}{ kendala selama belajar } \\
\hline 7 & $\begin{array}{l}\text { Menguasai materi dengan } \\
\text { mudah }\end{array}$ & 90 & 10 \\
\hline 8 & $\begin{array}{l}\text { Mengerjakan tugas } \\
\text { dengan mudah }\end{array}$ & 97 & 3 \\
\hline 9 & $\begin{array}{l}\text { Memberikan contoh } \\
\text { sehingga mudah } \\
\text { dimengerti }\end{array}$ & 100 & 0 \\
\hline 10 & $\begin{array}{l}\text { Mengikuti pembelajaran } \\
\text { dengan sungguh-sungguh }\end{array}$ & 87 & 13 \\
\hline 11 & $\begin{array}{l}\text { Ingin mendapatkan hasil } \\
\text { belajar yang maksimal }\end{array}$ & 97,6 & 2,4 \\
\hline 12 & $\begin{array}{l}\text { Menyelesaikan tugas } \\
\text { dengan baik secara } \\
\text { kelompok maupun } \\
\text { induvidu }\end{array}$ & 95 & 5 \\
\hline & Rata-rata & 92,6 & 7,4 \\
\hline
\end{tabular}

\begin{abstract}
Berdasarkan hasil penelitian dapat disimpulkan bahwa penggunaan media pembelajaran sebagai sumber belajar booklet science for kids pada materi sifat dan perubahan benda praktis dengan respon positif sebanyak rata-rata $92,6 \%$.
\end{abstract}

\section{Keefektivitas}

Hasil penilaian efektivitas media pembelajara booklet science for kids materi sifat dan perubahan benda di kelas VB, dilakukan dengan hasil dari lembar soal siswa pada setiap lembar kerja per-individu. Terlihat pada tabel 3

Tabel 4 Hasil Belajar Siswa Menggunakan Media Booklet Science for Kids

\begin{tabular}{ccccc}
\hline No. & Nama/ Inisial & Nilai & Persentase & Kriteria \\
\hline 1. & RMZ & 80 & $80 \%$ & Efektif \\
2. & RH & 100 & $100 \%$ & Efektif \\
3. & MSY & 80 & $80 \%$ & Efektif \\
4. & $\mathrm{AS}$ & 75 & $75 \%$ & Efektif \\
5. & $\mathrm{SW}$ & 75 & $75 \%$ & Efektif \\
6. & $\mathrm{MF}$ & 90 & $90 \%$ & Efektif \\
7. & $\mathrm{NA}$ & 90 & $90 \%$ & Efektif \\
8 & $\mathrm{MM}$ & 80 & $80 \%$ & Efektif \\
9. & $\mathrm{AB}$ & 75 & $75 \%$ & Efektif \\
10. & $\mathrm{DAM}$ & 100 & $100 \%$ & Efektif \\
\hline & Rata-rata Nilai Siswa & 84,5 & $84,5 \%$ & Efektif \\
\hline
\end{tabular}

Berdasarkan hasil analisis diatas bahwa ketuntasan bahwa hasil belajar siswa kelas VB mencapai $84,5 \%$ dengan rata-rata kelas 84,5 artinya jumlah siswa yang memperoleh nilai $\geq 75$, berarti dapat disimpulkan bahwa pembelajaran menggunakan booklet science for kids materi sifat dan perubahan benda memberikan pengaruh positif terhadap hasil belajar siswa. Sehingga media booklet science for kids materi sifat dan perubahan benda sebagai sumber belajar terbukti efektif dalam meningkatkan hasil belajar siswa.

\section{PEMBAHASAN}

Media pembelajaran yang telah dikembangkan berdasarkan analisis kebutuhan yaitu media booklet science for kids kemudian dipadukan dan dikaitkan dengan implikasinya dalam kehidupan sehari-hari dan disampaikan dalam suasana yang menyenangkan.

Media booklet science for kids sebagai fasilitas sumber belajar untuk siswa SD sudah diimplementasi sebagai salah satu media pembelajaran. Dari data yang diperoleh baik dari guru dan siswa menyatakan bahwa

Copyright $@ 2018$, JRPD, ISSN 2615 - 1723 (Print), ISSN 2615 - 1766 (Online) 
mereka lebih tertarik dan senang untuk belajar melalui sumber belajar media booklet science for kids.

Pada dasarnya penyajian booklet ini menggunakan banyak gambar dan warna sehingga memberikan tampilan yang menarik. Siswa cenderung menyukai bacaan yang menarik dengan sedikit uraian dan banyak gambar atau warna menurut Suwarto, et al. (2011). Hal tersebut karena gambar dapat meningkatkan minat baca karena gambar dapat membantu pembaca berimajinasi. Imajinasi dapat membantu seseorang meningkatkan kinerja ingatannya (Suharman, 2005:99).

Pada tahap pengembangan media booklet science for kids diawali dengan validasi oleh tim ahli yaitu ahli materi, ahli media, dan tim guru. Tahap ini bertujuan memvalidkan media pembelajaran yang dikembangkan sebelum diuji cobakan. Selain itu, uji kelayakan terhadap media booklet science for kids perlu dilakukan guna mengetahui kelayakan media tersebut sebelum digunakan dalam pembelajaran.

Berdasarkan penilaian dari validator media, kelebihan booklet ini terletak pada kemudahan penggunaan dan kesederhanaannya. Hasil penilaian tersebut sejalan dengan pendapat Imtihana, et al. (2014) bahwa booklet merupakan media sebagai sumber belajar yang sesuai dan layak untuk digunakan dan dapat dibaca dimanapun dan kapanpun sehingga dapat membantu meningkatkan pemahaman siswa terhadap materi.

Dengan adanya media booklet science for kids ini akan menjadi salah satu kriteria dalam membuat atau memilih sumber belajar media berbentuk booklet yang telah dibuat. Menurut penjelasan Ali (2009) kriteria pemilihan media bersumber dari konsep bahwa media merupakan bagian dari sistem instruksional secara keseluruhan. Ada beberapa faktor yang perlu dipertimbangkan adalah memilih media, yaitu : (1) Faktor yang menyangkut keluwesan, kepraktisan dan ketahanan media yang bersangkutan untuk waktu yang lama, artinya bisa digunakan dimanapun dan peralatan yang ada disekitarnya dan kapanpun serta mudah dijinjing dan dipindahkan, dan (2) Efektifikas penggunaan media bisa digunakan dalam jangka waktu yang lama.

Media booklet science for kids merupakan media berbasis teknologi catak, yang digunakan untuk menyajikan informasi dalam bentuk yang menyenangkan, menarik, mudah dimengerti, dan jelas. Media berbasis teknologi cetak adalah cara untuk menyampaikan materi, seperti buku dan materi visual statis terutama melalui proses pencetakan mekanis atau fotografis. Kelompok media hasil teknologi cetak meliputi teks, grafik, foto atau representasi fotografik dan reproduksi. Materi cetak dan visual merupakan dasar pengembangan dan penggunaan kebanyakan materi pembelajaran lainnya.

Secara keseluruhan siswa pada uji coba memberikan tanggapan positif terhadap media booklet science for kids alasannya yaitu karena booklet ini memberikan penampilan bahan ajar yang banyak menggunakan penjelasan berupa gambar serta warna-warna yang menarik, sehingga siswa merasa tertarik dan senang saat melihat buku booklet science for kids. Selain itu siswa juga menyukai pembelajaran yang sifatnya mengaitkan materi dengan kejadian dalam kehidupan sehari-hari di sekitar mereka. Hal tersebut dimaksudkan karena selama ini media yang digunakan kurang variatif sehingga siswa terkesan bosan dan kurang memperhatikan apa yang disampaikan oleh guru dan siswa juga merasa mengalami kesulitan apabila materi yang diterima terlalu banyak.

Pada penggunaan media pembelajaran booklet Science for kids sebagai sumber belajar terlihat baik dan mendapat respon positif dari siswa. Hal tersebut sejalan dengan pendapat Sudrajat (2008) bahwa sumber belajar (learning resources) adalah semua sumber baik berupa data, orang dan wujud tertentu yang dapat digunakan oleh peserta didik untuk belajar, baik secara terpisah maupun secara 


\section{Jurnal Riset Pendidikan Dasar, 01 (1), April 2018 (10-17)}

Tiurida Intika

terkombinasi sehingga mempermudah peserta didik dalam mencapai tujuan belajar atau mencapai kompetensi. Adapun penjelasan seorang ahli pendidikan menurut Edgar Dale (dalam Karwono, 2007) yang mengemukakan bahwa sumber belajar adalah segala sesuatu yang dapat dimanfaatkan untuk memfasilitasi belajar seseorang.

Materi yang disajikan dalam booklet science for kids merupakan materi sifat dan perubahan benda, khususnya benda-benda yang ada dikehidupan sehari-hari seperti di rumah, sekolah seperti benda padat, cair, dan gas yang ada disekitar lingkungan siswa.

Selain itu booklet science for kids yang berisikan tentang informasi-informasi penting disertai gambar ilustrasi memudahkan peserta didik menggunakan dalam proses pembelajaran. Hal tersebut karena booklet bersifat informatif, desainnya yang menarik dapat menimbulkan rasa ingin tahu, sehingga peserta didik bisa memahami dengan mudah apa yang disampaikan dalam proses pembelajaran.

Pada saat proses pembelajaran guru akan membimbing siswa dalampembelajaran dengan menggunakan media booklet science for kids. Pengembangan media booklet science for kids pada materi sifat dan perubahan benda yang diharapkan dapat meningkatkan hasil belajar siswa dalam belajar dan penggunaannya pada pembelajaran sains dapat membantu guru untuk menumbuhkan rasa ingin tahu siswa terhadap benda-benda yang ada di sekitar mereka.

Penggunaan media booklet science for kids memberikan pengaruh positif terhadap hasil belajar siswa. Terlihat dari hasil penelitian yang menunjukkan bahwa media booklet science for kids materi sifat dan perubahan benda sebagai sumber belajar terbukti efektif dalam meningkatkan hasil belajar siswa. Hal tersbeut sejalan pendapat pendapat sederhana menurut Duron (2006) hasil belajar merupakan pemikiran-pemikiran yang menunjukkan suatu hasil dari menganalisis dan mengevaluasi suatu informasi yang terdapat pada berpikir kritis untuk menghasilkan suatu hasil yang efektif.

Dengan begitu, untuk mengatakan bahwa media pembelajaran booklet science for kids itu efektif adalah perubahan yang membawa pengaruh maupun manfaat belajar bagi siswa itu sendiri. Perubahan itu bisa dari kemampuan berpikir baik pengetahuan, pemahaman, sikap dan keterampilan seseorang setelah belajar sehingga dari tidak tahu menjadi tahu, dan dari tidak mengerti menjadi mengerti. Adapun pendapat bahwa pembelajaran yang efektif ditandai dengan sifatnya yang menekankan pada pemberdayaan siswa secara aktif (Khikmah, 2012).

Berdasarkan hasil survey dan uji coba terhadap sample 10 siswa keberadaan media pembelajaran booklet Science for kids sebagai sumber belajar pada materi sifat dan perubahan benda ini sangat membantu guru dan siswa dalam memahami materi meningkatkan semangat belajar siswa, kompetesi, dan tujuan pembelajaran yang telah direncanakan.

\section{SIMPULAN}

Berdasarkan hasil dan pembahasan, maka dapat disimpulkan : (1) Booklet Science for Kids dikembangkan berdasarkan hasil analisis angket kebutuhan pengembangan oleh guru dan angket observasi awal oleh siswa. (2) Pengembangan booklet Science for Kids merupakan proses pembuatan materi pembelajaran berbentuk booklet sebagai sumber belajar untuk siswa kelas V. Booklet efektif digunakan Science for Kids sebagai sumber belajar terlihat dari hasil belajar siswa pada materi sifat dan perubahan benda mencapai ketuntasan belajar. (4) Hasil penelitian pengembangan media pembelajaran IPA berupa booklet Science for Kids untuk menghasilkan media pembelajaran yang memenuhi kriteria valid, praktis, dan efektif. (5) Penilaian terhadap kepraktisan booklet Science for Kids sangat baik (92,6\% siswa), 
booklet mudah dibawa, ringan, dan materi yang sudah terangkum sehingga ringkas dan mudah dipahami karena berkaitan dengan lingkungan.

\section{Saran}

Dari penelitian yang telah dilakukan, penulis menyarankan beberapa hal sebagai berikut.

1. Perlunya mengembangkan media booklet untuk materi lain, sehingga siswa merasa termotivasi dan lebih tertarik belajar.

2. Untuk pengembangan media pembelajaran selanjutnya, lebih baik dilengkapi CD sehingga lebih interaktif lagi.

3. Diharapkan akan ada penelitian lebih lanjut seperti penelitian desain untuk lebih membuat penggunaan media booklet lebih interaktif dalam pembelajaran di kelas.

4. Dapat dimanfaatkan oleh guru maupun tenaga pengajar lainnya sebagai alat untuk membantu proses pembelajaran secara klasikal maupun individu.

\section{DAFTAR PUSTAKA}

Ali, M. (2009). Pengembangan Pembelajaran Interaktif Mata Kuliah Medan Elektromagnetik. Jurnal Edukasi@Elektro.5(1): 11-18.

Arsyad, A. (2010). Media pembelajaran. Jakarta: Bumi Aksara.

Darmoko. (2012). Pengaruh Media Booklet Terhadap Peningkatan Pengetahuan Petani. Jurnal Penelitian Pertanian. 2(13): 57-68.

Duron, R. (2006). Critical Thinking Framework For Any discipline. International Journal of Teaching and Learning in Higher Education. 17(2): 160166.

Imtihana, M., Martin, P., \& Priyono, B. (2014). Pengembangan Buklet Berbasis Penelitian Sebagai Sumber belajar Materi Pencemaran Lingkungan di SMA. Unnes Journal of Biology Education. 3 (2) (2014) 186-192.

Karwono. (2007). Pemanfaatan Sumber Belajar dalam Upaya Peningkatan Kualitas dan Hasil Pembelajaran. Jakarta : Metro.
Khikmah. 2012. Makalah Pembelajaran Efektif (The Effective Leson). Purwokerto : STAIN.

Mayer, R.E. (2009). Multimedia Learning Prinsip-Prinsip Dan Aplikasi. Surabaya: ITS Press.

Nur, F. (2012). Pemanfaatan sumber belajar dalam pembelajaran sains kelas V SD pada pokok bahasan makhluk hidup dan proses kehidupan. Jurnal Penelitian Pendidikan. 13(1): 67-78.

Parveen, Q. (2011). Effect of Cooperative Learning on Achievement of Students in General Science at Secondary Level. International Journal or Academic Research, 3(1):134-152.

Pralisaputri, K.R., Soegiyanto, H., \& Muryani. C. (2016). Pengembangan Media Booklet Berbasis SETS Pada Materi Pokok Mitigasi dan Adaptasi Bencana Alam Untuk Kelas X SMA. Jurnal GeoEco. 2(2): 147-154.

Sudrajat, A. (2008). Pengertian Pendekatan, Strategi, Metode, Teknik dan Model Pembelajaran. Bandung : Sinar Baru Algensindo.

Sugiyono. (2015). Metode Penelitian Pendidikan (Pendekatan Kuantitatif, Kualitatif, dan $R \& D)$. Bandung: Alfabeta.

Suharman. (2005). Psikologi Kognitif. Surabaya: Srikandi.

Suwarto, WA., Hadiyah., \& Amir. (2011). Penggunaan Media Audio Visual Untuk Meningkatkan Hasil Belajar PKN. [Online]. Tersedia di: http://jurnal.fkip.uns.ac.id/index.php /pgsdsolo/article/view/73Suwarto.pdf. Diakses 25 Januari 2018. 